\title{
Labyrinthe
}

31 | 2008 (3)

Revues modes d'emploi

\section{"Je sais et j'ai les preuves. Et donc je raconte..."}

Sur Gomorra de Roberto Saviano

\section{Renaud Pasquier}

\section{(2) OpenEdition}

Journals

Édition électronique

URL : http://journals.openedition.org/labyrinthe/3880

DOI : $10.4000 /$ labyrinthe.3880

ISSN : 1950-6031

Éditeur

Hermann

Édition imprimée

Date de publication : 15 octobre 2008

ISBN : 978-2-9526131-8-7

Référence électronique

Renaud Pasquier, «" "Je sais et j'ai les preuves. Et donc je raconte..." », Labyrinthe [En ligne], 31 | 2008

(3), mis en ligne le 08 novembre 2008, consulté le 24 septembre 2020. URL : http://

journals.openedition.org/labyrinthe/3880 ; DOI : https://doi.org/10.4000/labyrinthe.3880

Ce document a été généré automatiquement le 24 septembre 2020.

Propriété intellectuelle 


\section{"Je sais et j'ai les preuves. Et donc je raconte..."}

Sur Gomorra de Roberto Saviano

Renaud Pasquier

INDEX

Mots-clés : Italie 